\title{
Artikel
}

\section{Antecedentenscreening in de financiële sector}

\author{
Een empirische blik op integriteitswaarborging door de uitwisseling en beoordeling van \\ antecedenten
}

\section{Inleiding}

De integriteit van instellingen, ondernemingen en professionals in de financiële sector wordt als een groot goed beschouwd. Om deze te bewaken bestaat er binnen de sector een veelsoortigheid aan toezicht- en handhavingsinstrumenten. Een combinatie van bestuursrechtelijke, strafrechtelijke en tuchtrechtelijke wet- en regelgeving is voorhanden om normconform en integer gedrag te bewaken en te bevorderen. Daarnaast bestaan tal van toetsings- en screeningsinstrumenten met behulp waarvan de integriteit van ondernemingen en professionals kan worden beoordeeld. In al deze vormen van integriteitstoetsingen speelt de vraag of en in hoeverre in het verleden sprake is geweest van normoverschrijdend gedrag. Die vraag wordt mede beantwoord door onderzoek te doen naar zogenoemde antecedenten, hier te omschrijven als alle formele reacties op normoverschrijdend gedrag. Deze antecedenten kunnen zowel bestaan uit strafrechtelijke sancties als uit bestuursrechtelijke of tuchtrechtelijke reacties op normoverschrijdend gedrag.

Vanaf de jaren negentig van de vorige eeuw zien we dat de focus van een strafrechtelijke aanpak verschuift naar een combinatie van strafrechtelijke handhaving en een bestuursrechtelijke aanpak. Onderdeel van deze 'dub-

Dr. mr. E.G. van 't Zand is universitair docent criminologie. Prof. mr. dr. P.M. Schuyt is hoogleraar sanctierecht en straftoemeting. Prof. mr. J.H. Crijns is hoogleraar straf- en strafprocesrecht. belstrategie' is meer aandacht voor preventie op basis van screening, waartoe een breed palet aan bestuursrechtelijke maatregelen werd geïntroduceerd. Zo werd met de Bibob-toetsing beoogd ondermijning van de integriteit van de overheid te voorkomen. ${ }^{1}$ Ook de Verklaring Omtrent het Gedrag kreeg een prominente rol toebedeeld in criminaliteitspreventie, ${ }^{2}$ en werd - net als het Landelijke Bureau Bibob - ondergebracht bij de in 2004 opgerichte screeningsautoriteit Justis van het ministerie van Justitie en Veiligheid. De samenwerking tussen strafrechtelijke instanties, screeningsinstanties en toezichthoudende instanties is sindsdien sterk geintensiveerd. Verschillende overkoepelende verbanden werden opgericht met het doel informatiedeling gemakkelijker te maken. ${ }^{3}$ Deze 'geïntegreerde handhavingsketen' is niet meer weg te denken uit het handhavingslandschap. ${ }^{4}$ Het in 2019 geagendeerde nationaal plan van aanpak witwassen acht samenwerking ${ }^{5}$ van doorslaggevend belang. ${ }^{6}$ Ook de in 2017 geïntroduceerde Toekomstagenda Ondermijning stelt een verscherpte aanpak voor

1. B. van der Vorm, Ernstig gevaar: Een juridisch-empirisch onderzoek naar aard, doel en toepassing van de Wet Bibob, Oisterwijk: Wolf Legal Publishers 2016.

2. E.G. van 't Zand-Kurtovic, Invisible bars; The impact of having a criminal record on young adults' position in the labour market (diss. Universiteit Utrecht), The Hague: Eleven International Publishing 2017.

3. Zoals de Zorg- en Veiligheidshuizen (ZVH's), de Regionale Informatieen Expertisecentra (RIEC's), het Financieel Expertise Centrum (FEC) en de infobox Crimineel en Onverklaarbaar Vermogen (iCOV).

4. M.J.J.P. Luchtman, 'Samenwerkingsverbanden en de strafrechtspleging', TBS\&H, 2020-5, p. 222-235.

5. Waaronder informatie-uitwisseling tussen poortwachters als de toezichthouders, de FIU-Nederland, de opsporingsdiensten, het $\mathrm{OM}$ en het kabinet.

6. Brief van de Ministers van Financiën en Justitie en Veiligheid van 27 januari 2021 (Kamerstukken I/ 2018/19, 31477, nr. 41). 
middels een breed offensief, waarin diverse ministeries, strafrechtelijke instanties, gemeenten, toezichthouders en samenwerkingsverbanden samen optrekken. ${ }^{7}$ Het brede scala aan nieuwe wetgeving om ondermijning tegen te gaan richt zich vooral op het uitbreiden van preventieve screening voor het detecteren van nietinteger gedrag. ${ }^{8}$ Zo wordt gegevensverwerking door samenwerkingsverbanden gereguleerd, ${ }^{9}$ is de Wet Bibob uitgebreid om meer bevoegdheden te creëren voor informatiedeling van overheden onderling, ${ }^{10}$ en wordt beoogd de VOG-screening te verruimen aan de hand van politiegegevens. ${ }^{11}$

Het moge duidelijk zijn dat op verschillende manieren op normoverschrijdend gedrag kan worden gereageerd. Ook bij het bepalen van de integriteit van een onderneming of een professional in de financiële sector kunnen derhalve verschillende soorten antecedenten van belang zijn: strafrechtelijke antecedenten, maar ook (fiscaal) bestuursrechtelijke antecedenten, toezichtantecedenten, financiële antecedenten en tuchtrechtelijke antecedenten. Daarbij wordt gebruik gemaakt van verschillende mogelijkheden tot gegevensdeling, zowel tussen toezichthouders onderling - onder andere via samenwerkingsverbanden - als tussen toezichthouders en beroepsorganisaties.

Het gevaar van deze veelheid aan routes, die elkaar wederzijds beïnvloeden en deels overlappen, is dat het onduidelijk wordt wat de gevolgen kunnen zijn van een bepaalde reactie op normoverschrijdend gedrag. Of meer concreet, hoe lang, op welke wijze en in welke contexten bepaalde antecedenten kunnen doorwerken. Mede vanuit het perspectief van individuele rechtsbescherming - maar ook vanuit het perspectief van effectieve preventie van toekomstig normoverschrijdend gedrag - is het van belang de verschillende vormen van integriteitstoetsing in kaart te brengen en te onderzoeken in hoeverre sprake is van een logische en consistente constellatie. De logica en consistentie van het geheel is des te belangrijker nu door nieuwe, overkoepelende offensieven in combinatie met een steeds verdergaande digitalisering in toenemende mate onderling gegevens worden uitgewisseld.

Onlangs hebben wij, onder begeleiding van het WODC, een juridisch-empirisch onderzoek verricht naar de

7. Brief van de Minister van Justitie en Veiligheid van 14 juli 2017 (Kamerstukken /l 2016/17, 29911, nr. 167).

8. 'Factsheet voor professionals over de stand van zaken ondermijningswetgeving' Rijksoverheid.nl (te raadplegen via www.rijksoverheid.nl/ binaries/rijksoverheid/documenten/publicaties/2020/04/06/factsheetvoor-professionals-over-de-stand-van-zaken-ondermijningswetgevingper-1-april-2020/Factsheet+voor+professionals+over+de+stand+van +zaken+ondermijningswetgeving+per+1+april+2020.pdf).

9. Kamerstukken I/ 2019/20, 35447, nr. 2 (Wetsvoorstel gegevensverwerking door samenwerkingsverbanden)

10. Wijziging van de Wet bevordering integriteitsbeoordelingen door het openbaar bestuur in verband met informatiedeling tussen bestuursorganen en rechtspersonen met een overheidstaak en enige overige wijzigingen, Stb. 2020, 278.

11. Kamerstukken I/ 2019/20, 35355, nr. 2 (Wetsvoorstel weigeren VOG op basis van politiegegevens). vraag in hoeverre het realiseerbaar en wenselijk is om bestuurlijke boetes bij de VOG-screening te betrekken. ${ }^{12}$ In dit onderzoek zijn onder meer experts geïnterviewd van instanties die een rol spelen bij het bewaken en bevorderen van integriteit binnen de financiële sector. Met behulp van deze interviews hebben wij zicht gekregen op de wijze(n) waarop elk van deze instanties de integriteit van de financiële professionals en/of instellingen die onder haar taakstelling vallen, beoordeelt alsmede op de mogelijkheden die er zijn om toezicht te houden op de naleving van integer gedrag. Wij interviewden achtentwintig experts van zestien verschillende (afdelingen van) instanties tot wier taak het behoort de integriteit in deze sector te waarborgen. Dit betroffen: (1) screeningsautoriteit Justis (afdelingen COVOG, LBB, TRACK); (2) toezichthoudende en handhavende instanties (ACM, AFM, Belastingdienst, BFT, DNB); (3) beroeps- of brancheorganisaties (Adfiz, DSI, NBA, NOB, Stichting Tuchtrecht Banken); (4) overige relevante instellingen (FEC, iCOV, ministerie van Financiën). ${ }^{13}$ Via al deze experts zijn waardevolle inzichten verkregen in de verschillende aspecten van integriteitstoetsing.

In deze bijdrage geven wij op basis van deze bevindingen een overzicht van de wijzen waarop verschillende antecedenten een rol spelen bij de diverse vormen van integriteitstoetsing en -screening binnen de financiële sector. Daartoe beschrijven we eerst de verschillende integriteitsinstrumenten die binnen deze sector (kunnen) worden gehanteerd door screeningsinstanties, toezichthouders en beroepsorganisaties om integriteit binnen de sector te waarborgen, evenals welke bronnen daarbij kunnen worden betrokken (paragraaf 2). Daarna gaan wij in op de vraag hoe aan het beoordelen van de integriteit uitvoering wordt gegeven in de praktijk (paragraaf 3). Allereerst vanaf welk moment antecedenten in de integriteitsbeoordeling betrokken kunnen worden en vervolgens hoe de weging hiervan plaatsvindt en op welke wijze waarde aan verschillende typen antecedenten kan worden toegekend. Ook bespreken wij enkele praktische obstakels verbonden aan het betrekken van verschillende informatiebronnen bij integriteitstoetsing. In de slotbeschouwing (paragraaf 4) maken wij de balans op en werpen wij licht op de vraag in hoeverre het huidige integriteitsinstrumentarium binnen de financiële sector als een logisch en consistent geheel kan worden beschouwd.

12. E.G. van 't Zand, J.H. Crijns, P.M. Schuyt, M.M. Boone \& M.L. van Emmerik, Bestuurlijke boetes en de Verklaring Omtrent het Gedrag: een onderzoek naar de realiseerbaarheid en wenselijkheid van het betrekken van bestuurlijke boetes bij de VOG-screening aan de hand van een casestudy naar handhaving en integriteit in de financiële sector, Meijers-reeks nr. 354, Den Haag: Boom juridisch 2020.

13. Van 't Zand e.a. 2020, hoofdstuk 2. 


\section{Integriteitstoetsingen en -screenings}

In deze paragraaf inventariseren we de verschillende instrumenten die worden gehanteerd om integriteit binnen de sector te waarborgen. We presenteren de instrumenten die worden ingezet door, screeningsinstanties (2.1), toezichthouders (2.2) en beroepsorganisaties (2.3), ${ }^{14}$ waarbij per instrument wordt ingegaan op een viertal kenmerken: het aantal geraadpleegde bronnen, de frequentie (eenmalig of doorlopend), het (potentiële) bereik en de (feitelijke) omvang van de screening. Onder het bereik verstaan wij de reikwijdte van de doelgroepen die in potentie onder de screening vallen, terwijl de omvang ziet op het aantal feitelijk uitgevoerde toetsingen en screenings. Op basis van deze inventarisatie zal duidelijk worden dat het landschap van integriteitstoetsingen en -screenings zeer weids en divers is.

\subsection{Integriteitsbeoordelingen door screeningsinstanties}

- $\quad$ Screening via de Verklaring Omtrent het Gedrag

Natuurlijke personen of rechtspersonen die een Verklaring Omtrent het Gedrag aanvragen, worden gescreend door de afdeling Centraal Orgaan Verklaring Omtrent het Gedrag (COVOG) van screeningsautoriteit Justis. Aangezien een VOG voor iedere denkbare baan verplicht kan worden gesteld, ${ }^{15}$ heeft dit screeningsinstrument het meest vergaande bereik. Door (rechts)personen te screenen op een justitieel verleden wordt beoogd risico's voor de samenleving te beperken:

'Onze Minister meigert de afgifte van een verklaring omtrent het gedrag, indien in de justitiële documentatie met betrekking tot de aanvrager een strafbaar feit is vermeld, dat, indien herhaald, gelet op het risico voor de samenleving en de overige omstandigheden van het geval, aan het doel waarvoor de verklaring omtrent het gedrag mordt gevraagd, in de meg zal staan.' (artikel $35 \mathrm{Wjsg}$ )

Enkel indien sprake is van strafrechtelijke antecedenten die in de weg staan aan de behoorlijke uitoefening van de functie, taak of bezigheid waarvoor de VOG is angevraagd, kan deze worden geweigerd. Voor de beoordeling kunnen weliswaar aanvullende gegevens worden opgevraagd, ${ }^{16}$ deze kunnen echter enkel meewegen 'ter inkleuring' van het risico. Zij vormen geen zelfstandige weigeringsgrond. Dat een risico enkel aan de hand van justitiële gegevens vastgesteld wordt, biedt wellicht tegenwicht aan het vergaande bereik van dit instrument. De VOG kan namelijk ook buiten de context van

14. De samenwerkingsverbanden FEC en iCOV zijn in deze bijdrage buiten beschouwing gelaten. Meer hierover is te vinden in Van 't Zand e.a. 2020, par. 5.4.

15. Paragraaf 2.1 Beleidsregels VOG-NP-RP 2018, Stcrt. 2017, 68620.

16. De minister kan kennisnemen van politiegegevens en (t.a.v. rechtspersonen) van registraties bij de afdeling TRACK. Daarnaast kan de minister inlichtingen inwinnen bij het $O M$ en de reclasseringsinstellingen (art. 36 lid 1, 2 en 3 Wjsg). (on)bezoldigde werkrelaties een rol spelen, zoals bij stages, inschrijvingen of vergunningen die gelden voor bepaalde beroepsgroepen en voor politieke ambtsdragers en bestuurders. Ook rechtspersonen kunnen worden gescreend. De VOG-screening lijkt in potentie het sluitstuk te kunnen vormen van screening in de financiële sector. Iedere professional of onderneming die niet valt onder de specifieke toetsingen die hierna worden besproken, kan altijd worden gescreend op een justitieel verleden via de VOG. In de financiële sector geldt doorgaans dat de VOG bij anvang van het dienstverband door de werkgever wordt vereist en er eenmalig wordt gescreend. ${ }^{17}$ Tussen 2015 en 2019 werden jaarlijks gemiddeld tegen de 65.000 aanvragen gedaan op basis van het specifieke screeningprofiel 'financiële dienstverlening' ${ }^{18}$ In 2015 werden 36 van deze aanvragen afgewezen en in 201943 (beide $0,06 \%$ ). ${ }^{19}$ Het antal aanvragen voor een VOG voor rechtspersonen lag tussen 2013 en 2019 op circa 5.500 per jaar, waarbij het aantal weigeringen tussen de 1 en de 10 lag. ${ }^{20}$

- $\quad$ Controle op rechtspersonen door TRACK

De screening die zowel qua omvang als qua frequentie het meest grootschalig lijkt, is die van de afdeling TRACK van screeningsautoriteit Justis. Daar wordt namelijk continu toezicht uitgeoefend op alle in het handelsregister van de $\mathrm{KvK}$ ingeschreven rechtspersonen:

'Onze Minister controleert rechtspersonen met het oog op de voorkoming en bestrijding van misbruik van rechtspersonen, maaronder het plegen van misdrijven en overtredingen van financieel-economische aard door of door middel van deze rechtspersonen.' (artikel 2 lid 1 Wet controle op rechtspersonen)

Dit doorlopend toezicht vangt aan vanaf het moment van registratie in het $\mathrm{KvK}$-handelsregister. Wanneer er in dit register een wijziging plaatsvindt, gaat het automatische analysesysteem RADAR draaien. ${ }^{21}$ Per jaar monden er rond de anderhalf miljoen $\mathrm{KvK}$-wijzingen uit in 200.000 automatische analyses. ${ }^{22}$ Zodoende is niet alleen het bereik van de screening van TRACK fors, maar vindt deze ook nog eens continu plaats. Met behulp van RADAR vindt geautomatiseerd een eerste bronbevraging plaats. Naast het KvK-register betreft dit de Basisregistratie Personen, het Centraal Insolventieregister en het Justitieel Documentatiesysteem. Het analysesysteem 'scoort' dus niet alleen op justitiële antece-

17. Al kan een werkgever een periodieke hertoetsing verplicht stellen. In andere branches - de taxibranche en de kinderopvang - geldt een continue screening.

18. O. Nauta, N. Piepers en W. Buysse, Analyse beoordelingsstelsel VOG NP, Amsterdam: DSP-groep 2021.

19. Nauta e.a. 2021, p. 55 en Kruize en Gruter 2016, p. 65.

20. Zie hiervoor 'VI Justitie en Veiligheid Rijksbegroting', Rijksoverheid.nl en 'Jaarverslag Justis', Justis.nl.

21. 'Brochure TRACK', Justis.nl (te raadplegen via https://justis.nl/binaries/ Brochure\%20Track_tcm34-305718.pdf).

22. 'Beleidsdoorlichting preventieve maatregelen', Rijksoverheid.nl (te raadplegen via https://www.rijksoverheid.nl/documenten/rapporten/ 2021/04/07/tk-bijlage-eindrapport-uitvoeren-beleidsdoorlichting). 
denten; ${ }^{23}$ ook faillissementen en ontbindingen worden gecheckt. Bovendien worden antecedenten van adresrelaties en familierelaties gecheckt. ${ }^{24}$ Als uit deze vier primaire bronnen geen 'indicatoren' naar voren komen, 'scoort' het systeem niet. KvK-indicatoren kunnen bijvoorbeeld bestaan uit bestuurswisselingen of buitenlandse bestuurders. Zijn er indicatoren, dan beoordeelt een analist of sprake is van een risico op misbruik. Hiervoor kan aanvullende bronbevraging plaatsvinden bij een groot aantal (minstens tien) instanties. ${ }^{25} \mathrm{Op}$ basis hiervan kan een risicomelding worden gedaan bij evenzoveel instanties met opsporing of toezicht belast. ${ }^{26}$ Tussen 2016 en 2019 werden op jaarbasis tussen de 1.100 en 1.888 risicomeldingen gedaan, ${ }^{27}$ dan wel netwerktekeningen verstrekt aan instanties met een publiekrechtelijke taak op het gebied van fraudebestrijding. ${ }^{28}$

\section{- $\quad$ Toetsing door het Landelijk Bureau Bibob}

De Wet Bibob is in het leven geroepen om te voorkomen dat de overheid criminele activiteiten, met name georganiseerde criminaliteit, faciliteert. Bibob-toetsing kan plaatsvinden bij vergunningen, transacties, subsidies en overheidsopdrachten op een uiteenlopend aantal terreinen als recreatie, vervoer, transport, milieu, omgeving, bouw en vastgoed. Bestuursorganen kunnen weigeren een beschikking te geven, of deze intrekken, indien:

\section{'[...] ernstig gevaar bestaat dat de beschikking mede zal} morden gebruikt om: (a) uit gepleegde strafbare feiten verkregen of te verkrijgen, op geld maardeerbare voordelen te benutten, of (b) strafbare feiten te plegen.' (artikel 3 lid 1 Wet Bibob)

Onder 'strafbare feiten' worden expliciet ook overtredingen geschaard waarvoor een bestuurlijke boete kan worden opgelegd. ${ }^{29}$ Het bestuursorgaan kan voor dit oordeel advies inwinnen bij het Landelijk Bureau Bibob (LBB) van screeningsautoriteit Justis. Jaarlijks worden tegen de 300 adviezen uitgebracht. ${ }^{30}$ Hiervoor wordt het

23. Van de oprichters, de aandeelhouders, de commissarissen, de leden - voor zover deze bestuurlijke functies vervullen -, de bestuurders en de vertegenwoordigers van een rechtspersoon (art. 4 lid 1 Wcr).

24. art. 4 lid $3 \mathrm{Wcr}$.

25. Dit kan bij de Belastingdienst, de politie, het $\mathrm{OM}$, rechtbanken, het UWV, de KMar, de FIU, Inspectiediensten, de bijzondere opsporingsdiensten en openbare bronnen. Zie art. 3 lid 1 en 2 Wcr en 'Factsheet Toezicht op Rechtspersonen' Justis.nl (te raadplegen via https:// justis.nl/binaries/Factsheet\%20Toezicht\%20op\%20rechtspersonen \%20november\%202020_tcm34-286022.pdf).

26. Volgens art. 5 lid $1 \mathrm{Wcr}$ jo. art. 5 a Besluit controle op rechtspersonen betreffen dit: AFM, DNB, OM, Belastingdienst, FIOD, ILT, NVWA, ISZW, bijzondere opsporingsdiensten, KMar, FIU.

27. 'VI Justitie en Veiligheid - Rijksjaarverslag 2019', Rijksoverheid.nl (te raadplegen via https://www.rijksoverheid.nl/binaries/rijksoverheid/ documenten/jaarverslagen/2020/05/20/justitie-en-veiligheid-2019/vijustitie-en-veiligheid.pdf).

28. 'Factsheet iCOV \& Justis/TRACK', Justis.nl (te raadplegen via https:// justis.nl/binaries/WEB_122911_FS_Track_ICOV_tcm34-415584.pdf).

29. art. 3 lid 8 Wet Bibob.

30. 'Jaarverslag LBB 2019', Justis.nl (te raadplegen via https://justis.nl/ binaries/Jaarverslag\%2OLandelijk\%20Bureau\%20Bibob \%202019_tcm34-452241.pdf). netwerk rond de betrokkene(n) in kaart gebracht, waarbij van een groot aantal bronnen gebruikgemaakt kan worden. Niet minder dan negentien bestuursorganen hebben een wettelijke verplichting alle door het LBB gevraagde gegevens te verstrekken, waaronder de afdeling TRACK, de Belastingdienst en de ACM. ${ }^{31}$ Hieruit kan een advies volgen over de 'mate van gevaar', waarop het bestuursorgaan vervolgens een weigering of intrekking van een beschikking kan baseren, aan een beschikking voorschriften kan verbinden of deze kan verlenen indien er geen gevaar is. ${ }^{32}$ Hoewel de Bibobtoetsing in potentie een breed bereik heeft, ligt het aantal Bibob-adviezen verhoudingsgewijs lager dan bij andere screeningsproducten. De omvang van het aantal adviezen dat wordt uitgebracht hangt af van hoe vaak, op welke terreinen en vanuit welke provincies bestuursorganen hiervan gebruikmaken. Hierin zijn grote verschillen zichtbaar. ${ }^{33} \mathrm{Bij}$ vergunningen in de horeca en de bouw wordt bijvoorbeeld vaker om advies gevraagd dan bij subsidies. Los daarvan heeft de Bibobtoetsing in potentie wel degelijk een groot bereik. Hierop zag ook de uitbreiding van de Wet Bibob per 2020, ${ }^{34}$ als gevolg waarvan nu alle overheidsopdrachten, dus niet alleen in bepaalde sectoren, getoetst kunnen worden. Te verwachten valt dat hiermee de Bibob-toetsing ook feitelijk steeds omvangrijker wordt.

\section{- $\quad$ Controle door Stichting DSI}

Stichting DSI is als niet-commercieel screeningsbedrijf opgericht ten behoeve van de certificering (van beleggingsprofessionals en complianceofficers) en screening van beleggingsprofessionals. De screening is uitsluitend gericht op de financiële sector en bedoeld voor de werknemers van instellingen die onder toezicht van DNB of de AFM staan. Deze toezichthouders stellen namelijk als eis aan de onder toezicht staande instellingen dat zij van hun werknemers een VOG verlangen ter voorkoming van integriteitsrisico's. Het overleggen van een VOG vormt zodoende een cruciaal onderdeel van de DSI-screening. Verder krijgt de professional een integriteitsvragenlijst voorgelegd en moeten bijvoorbeeld al diens werkgevers over de afgelopen vijf jaar een verklaring afgeven over de integriteit van de betreffende professional. DSI levert naar aanleiding hiervan een screeningsrapport op. $\mathrm{Zij}$ velt zelf geen oordeel over de integriteit van de professional, maar laat dit aan de werkgever. DSI-gecertificeerde professionals worden in een openbaar register opgenomen. Eventuele sancties die worden opgelegd door de Tuchtcommissie van DSI leveren een aantekening op. De AFM, op haar beurt, neemt bij de betrouwbaarheidstoetsing van beleidsbepalers de tuchtrechtelijke maatregelen uit dit openbaar register mee, evenals een beëindiging van de inschrijving bij DSI.

\footnotetext{
31. art. 27 Wet Bibob.

32. art. 3 lid 5, 6 en 7 Wet Bibob.

33. Jaarverslag LBB 2019 Justis.

34. Dit zijn o.a. degenen die (in)direct leidinggeven, zeggenschap hebben of vermogen verschaffen aan de betrokkene. Zie art. 15 lid 1 sub b en lid 2 Besluit justitiële en strafvorderlijke gegevens.
} 
2.2 Integriteitsbeoordeling door toezichthouders Voor financiële ondernemingen die onder toezicht staan van de AFM of DNB geldt de eis dat de betrouwbaarheid van beleidsbepalers en leden van toezichtsorganen zoals de Raad van Toezicht en Raad van Commissarissen (eerste echelon) buiten twijfel dient te staan:

'Het beleid van [een financiële onderneming] wordt bepaald of mede bepaald door personen wier betroumbaarheid buiten twijfel staat. Indien binnen de financiële onderneming een orgaan is belast met toezicht op het beleid en de algemene gang van zaken van de financiële onderneming mordt dit toezicht gehouden door personen mier betroumbaarheid buiten tmijfel staat.' (artikel 3:9 jo. $4: 10 \mathrm{Wft}$ )

Deze betrouwbaarheidseis is van overeenkomstige toepassing op leidinggevenden (tweede echelon) van een bank, kredietunie of verzekeraar, die uit hoofde van hun functie verantwoordelijk zijn voor natuurlijke personen wier werkzaamheden het risicoprofiel van de onderneming wezenlijk kunnen beinvloeden. ${ }^{35} \mathrm{Bij}$ de beleidsbepalerstoetsing worden naast strafrechtelijke antecedenten ook financiële antecedenten, toezichtantecedenten, fiscaal bestuursrechtelijke antecedenten en overige antecedenten in aanmerking genomen. ${ }^{36}$ Door de AFM vonden in de afgelopen jaren jaarlijks tussen de 1.474 (2017) en 1.946 (2019) eenmalige zogeheten aanvangstoetsingen plaats. ${ }^{37}$ Tussen de 11 en 32 daarvan bedroegen 'dubbele poortjes toetsingen', waarbij zowel door de AFM als DNB werd getoetst. Daarvan leidde ongeveer $95 \%$ tot een positief oordeel over de betrouwbaarheid. ${ }^{38}$ De integriteitstoets is qua bevraagde informatiebronnen vergaand, maar in beginsel eenmalig. Wel kan hertoetsing plaatsvinden als daartoe een 'redelijke aanleiding' bestaat. Dit vond tussen de zes en elf keer per jaar plaats tussen 2017 en $2019 .{ }^{39}$

\subsection{Integriteitsbeoordeling door} beroepsorganisaties en tuchtcolleges

Binnen het werkterrein van financiële professionals zijn diverse beroepsorganisaties actief. Wij hebben in het kader van ons empirisch onderzoek de Koninklijke Nederlandse Beroepsorganisatie van Accountants (NBA) en de Nederlandse Orde van Belastingadviseurs (NOB) kunnen spreken, evenals Stichting Tuchtrecht Banken. De op privaatrechtelijke leest geschoeide

35. Dit wil zeggen: personen werkzaam onder verantwoordelijkheid van een bank, kredietunie of verzekeraar met zetel in Nederland, die een leidinggevende functie vervullen direct onder het echelon van de beleidsbepalers en verantwoordelijk zijn voor natuurlijke personen wier werkzaamheden het risicoprofiel van de onderneming wezenlijk kunnen beïnvloeden.

36. art. 6 Besluit prudentiële regels Wft; art. 13 Besluit Gedragstoezicht financiële ondernemingen Wft. Dergelijke antecedenten kunnen bijvoorbeeld ook binnen het samenwerkingsverband FEC (Financieel Expertise Centrum) worden uitgewisseld.

37. 'Jaarverslag 2019', AFM.nl (te raadplegen via: www.afm.nl/ / profmedia/files/afm/jaarverslag/2019/afm-jaarverslag-2019.pdf?la=nl$\mathrm{NL})$.

38. Idem.

39. Idem. beroepsorganisaties en tuchtcolleges hebben geen directe mogelijkheid tot het uitvragen van bronnen van publieke instanties, zoals toezichthouders. Voor zogeheten toetsingen aan de poort zijn zij ofwel afhankelijk van de VOG ofwel van zelfmeldingen van (aspirant-)leden of gescreenden. Daarnaast kennen de beroepsorganisaties een onafhankelijke tuchtrechtprocedure, zodat bij wangedrag na toetreding alsnog maatregelen of ontzetting uit de beroepsgroep kunnen volgen.

De NBA is de wettelijk verplichte beroepsorganisatie voor accountants. Zonder registratie in het accountantsregister van de NBA mag deze beroepstitel niet gevoerd worden. Om lid te worden, geldt als formele eis dat de aanvrager over een VOG beschikt. ${ }^{40}$ Daarnaast wordt de inschrijving geweigerd, indien:

'[...] er, gelet op de antecedenten van de aanvrager, gegronde vrees bestaat dat de aanvrager zal handelen of nalaten in strijd met mettelijke voorschriften, de accountant betreffende, of dat zijn inschrijving in het accountantsregister op andere mijze de eer van de stand van accountants zal schaden.' (artikel 39 lid 1 sub e Wet op het accountantsberoep)

Naast de VOG worden geen bronnen geraadpleegd. Om de integriteit van leden te waarborgen staat, naast deze aanvangstoetsing, de weg naar de tuchtrechter open om doorhaling uit het register te bewerkstelligen. Dit vindt volgens onze respondenten bijvoorbeeld plaats naar aanleiding van mediaberichtgeving over een strafrechtelijke zaak tegen een accountant. Daarnaast kunnen de AFM en de Belastingdienst informatie verschaffen over fiscale of toezichtantecedenten. De AFM mag in uitzondering op haar geheimhoudingsplicht vertrouwelijke gegevens of inlichtingen die tot een tuchtklacht kunnen leiden met de NBA delen. ${ }^{41}$ De Belastingdienst legt op basis van een convenant primair geanonimiseerd gevallen van (vermoedelijk) ontoelaatbaar gedrag voor aan de $\mathrm{NBA},{ }^{42}$ zoals over boetes voor onrechtmatig gebruik van de accountantstitel en vergrijpboetes voor het doen van onjuiste aangifte. Slechts in zeer uitzonderlijke gevallen vraagt vervolgens de Belastingdienst de minister van Financiën om ontheffing van de geheimhoudingsplicht. $^{43}$

De NOB is een van de drie, niet wettelijk verplichte, beroepsverenigingen voor belastingadviseurs. Als lidmaatschapsvereiste geldt dat slechts als (aspirant-)lid kan worden toegelaten degene die:

'[...] niet strafrechtelijk is veroordeeld voor een misdrijf, aan mie geen bestuurlijke boete is opgelegd megens een

40. art. 38 lid 2 sub b jo. art. 39 lid 1 sub a Wet op het accountantsberoep.

41. art. 63e Wet toezicht accountantsorganisaties.

42. art. 3 onder a Convenant inzake de samenwerking bij het tegengaan van ontoelaatbaar gedrag van accountants tussen de Belastingdienst en het Koninklijk Nederlands Instituut van Registeraccountants en de Nederlandse Orde van Accountants-Administratieconsulenten, Stcrt. 2012, 12055.

43. art. 3 onder c Convenant. 
overtreding begaan bij zijn merkzaamheden en aan wie geen vergrijpboete is opgelegd als bedoeld in artikel 16 lid 3, dan wel indien zulks wel het geval is, de Commissie van Beoordeling oordeelt dat dit geen bezmaar vormt voor toelating tot het lidmaatschap.' (Artikel 6 lid 1 sub c Statuten Nederlandse Orde van Belastingadviseurs)

Buiten deze voorwaarde, waaraan (aspirant-)leden bij een verzoek tot toelating te kennen moeten geven te voldoen, vindt geen antecedentencheck plaats. Indien tijdens de uitoefening van het beroep alsnog een strafrechtelijke veroordeling of bestuurlijke boete volgt, geldt een meldplicht aan de NOB. Naar aanleiding daarvan kan een tuchtzaak volgen, met ontzegging van het lidmaatschap als gevolg. De Belastingdienst kan op eigen initiatief informatie delen met en een tuchtklacht indienen bij de NOB. Als gevolg van recente wetgeving kunnen vergrijpboetes, opgelegd aan belastingadviseurs voor overtredingen begaan tijdens de door hen beroepsmatig of bedrijfsmatig verleende bijstand (de zgn. medeplegersboetes), openbaar worden gemaakt door middel van publicatie op de website van de Belastingdienst. ${ }^{44}$

Op grond van de $\mathrm{Wft}$ moeten banken zorgdragen voor een effectief tuchtrecht, ondergebracht bij Stichting Tuchtrecht Banken, dat de integriteit van de bancaire sector beoogt te bewaken en te bevorderen. ${ }^{45}$ De stichting maakt enkel gebruik van openbare bronnen en informatie die zij van de banken krijgt aangeleverd in het kader van onderzoek. Zo kan zij, ingeval een bank is beboet, deze bank benaderen met de vraag of zij een melding wil doen over (mogelijk) betrokken bankiers. Het tuchtrecht kan zo een aanvulling vormen wanneer enerzijds de onderneming wordt beboet en anderzijds de toezichthouder niet ook een boete aan de betrokken natuurlijke personen oplegt. Via een tuchtrechtelijke procedure kan het individu alsnog worden aangesproken. Tuchtrechtelijke uitspraken worden vervolgens anoniem online gepubliceerd, maar ook in een register opgenomen waartoe banken toegang kunnen krijgen met het oog op een specifieke kandidaat in een sollicitatieprocedure.

\section{Het beoordelen van integriteit aan de hand van antecedenten}

$\mathrm{Nu}$ de verschillende integriteits- en screeningsinstrumenten in kaart zijn gebracht, is de vervolgvraag hoe het beoordelingsproces in de praktijk vorm krijgt. Het gaat allereerst om de vraag vanaf welk moment antecedenten

44. Wet van 18 december 2019 tot wijziging van enkele belastingwetten en enige andere wetten (Overige fiscale maatregelen 2020), Stb. 2019, 512, in werking vanaf 1 januari 2020.

45. art. 2, 'Statuten van Stichting Tuchtrecht Banken gevestigd te Amsterdam d.d. 13 november 2015' gebruikt mogen worden in de integriteitsbeoordeling (3.1). Verder om de wijze waarop waarde wordt toegekend aan de diverse soorten antecedenten, zoals de aard en ernst van de overtreden norm en de herkomst (3.2). Vervolgens gaan wij in op de vraag in hoeverre er discretionaire ruimte bestaat, evenals de mate waarin de onderliggende feiten en omstandigheden, ofwel het 'verhaal achter het antecedent,' een rol (kunnen) spelen (3.3). Wij sluiten af met het bespreken van enkele praktische knelpunten bij gegevensdeling (3.4).

\subsection{Het moment van betrekken}

Allereerst speelt de vraag vanaf welk moment antecedenten betrokken zouden moeten worden in de integriteitsbeoordeling. Van belang is in hoeverre het antecedent in rechte nog aantastbaar is. We zien hier een duidelijk verschil tussen antecedenten met een strafrechtelijke- en een bestuursrechtelijke herkomst. Bij strafrechtelijke antecedenten geldt de onherroepelijkheid niet als voorwaarde en worden ook openstaande zaken en lopende opsporingsonderzoeken betrokken. Het is dan aan de beoordelende instantie zelf om op grond van de achterliggende stukken een inschatting te maken van de ernst van de gerezen verdenking. Voor het betrekken van bestuursrechtelijke antecedenten geldt doorgaans dat een bestuursrechtelijk besluit in rechte onaantastbaar moet zijn geworden alvorens hierover informatie kan worden gedeeld. ${ }^{46}$

Meerdere respondenten van de toezichthouders wijzen erop dat dit kan betekenen dat een antecedent zo goed als 'oud nieuws' is alvorens het door een andere instantie kan worden meegewogen. Bij mededingingszaken of fiscale zaken kan er met gemak vijf jaar overheen gaan voordat een besluit onherroepelijk is geworden. Het onderzoek naar de overtreding kan op zichzelf al enkele jaren in beslag nemen en vervolgens kunnen er enkele jaren overheen gaan voordat men is 'uitgeprocedeerd' ${ }^{47}$ In acht nemende dat er tussen het begaan van de overtreding en het aan het licht komen ervan ook nog enkele jaren kunnen zitten, roept dit de vraag op of het, om een betrouwbare integriteitsbeoordeling te kunnen maken, niet nodig is antecedenten eerder te kunnen betrekken. Het heeft namelijk consequenties voor de betrouwbaarheid van de gemaakte beoordeling als op het moment van beoordelen niet precies kan worden ingeschat wat voor vlees men in de kuip heeft. Daarbij komt de vraag of het nog wel zinvol is een overtreding op het moment dat deze in rechte onaantastbaar is geworden, dat wil soms zeggen vijf tot wel tien jaar na het begaan ervan, 'ineens' in de beoordeling te betrekken. Een integriteitsoordeel is zodoende niet alleen altijd een momentopname, maar wordt in de praktijk ook nog eens tot op zekere hoogte als arbitrair ervaren.

Het betrekken van besluiten die nog niet onherroepelijk zijn, wordt door onze respondenten echter niet als

46. Van 't Zand e.a. 2020, par. 5.2.5

47. Met in uiterste gevallen ook nog de extra stap van het stellen van prejudiciële vragen aan het Hof van Justitie van de Europese Unie. 
oplossing gezien, omdat het behoorlijke gevolgen zou hebben voor de rechtsbescherming van de betrokkene. Het belang van een onafhankelijke rechterlijke toets van besluiten wordt vanuit verschillende hoeken benadrukt. Vaak onderhouden professionals en ondernemingen een duurzame, afhankelijke relatie met de toezichthouder. Zodoende is het belangrijk als rechtswaarborg te handhaven dat besluiten eerst in rechte dienen vast te staan, alvorens zij door andere instanties aan hun integriteitsoordeel ten grondslag kunnen worden gelegd. Met het oog op de rechtspositie van de betrokkene werd, tot slot, ook nog gewezen op de kenbaarheid van de gevolgen die aan een overtreding kunnen kleven. De impact die een antecedent kan hebben, kan een belangrijke beweegreden vormen een besluit tot oplegging van een sanctie of maatregel, dan wel een besluit tot publicatie daarvan, al dan niet aan te vechten. Uit het feit dat dit soort overwegingen kennelijk geen rol spelen indien het strafrechtelijke antecedenten betreft, kan worden geconcludeerd dat de herkomst van een antecedent op dit punt consequenties heeft voor de doorwerking daarvan in de integriteitstoetsing.

\subsection{Aard en ernst van de overtreding}

Om de integriteit te kunnen beoordelen, is het vervolgens van belang om te bepalen hoe 'zwaar' een eerdere normoverschrijding is geweest. In dit verband kan worden gekeken naar de aard en ernst van de overtreding. Daarbij wordt door beoordelaars in de eerste plaats onderscheid gemaakt tussen strafrechtelijke en andersoortige antecedenten. In alle besluitvormingsprocessen in het kader van integriteitstoetsingen en -screenings worden strafrechtelijke feiten qua aard en zwaarte duidelijk onderscheiden van bestuursrechtelijke overtredingen. ${ }^{48}$ Het LBB kijkt bijvoorbeeld naar 'feiten en omstandigheden die erop wijzen of redelijkerwijs doen vermoeden dat de betrokkene in relatie staat tot strafbare feiten' ${ }^{49}$ Strafrechtelijke afdoeningen wijzen op zo'n relatie. Andersoortige feiten en omstandigheden, zoals opsporings- en vervolgingsacties of (sommige) bestuurlijke boetes, kunnen daarentegen hooguit leiden tot een vermoeden van in relatie staan tot strafbare feiten. Bij de toetsing van beleidsbepalers is voorgeschreven dat de betrouwbaarheid niet buiten twijfel staat indien sprake is van een onherroepelijke veroordeling ter zake van nader bepaalde misdrijven. ${ }^{50}$ In tegenstelling tot andere typen antecedenten bestaat daarbij geen ruimte voor een nadere belangenafweging. ${ }^{51}$

Het is vooral de aard van strafrechtelijke antecedenten die het wegen ervan in de praktijk vrij ongecompliceerd maakt. Uit ons onderzoek is gebleken dat overtredingen van strafrechtelijke normen doorgaans min of meer per definitie als schadelijk voor de maatschappij worden

48. Van 't Zand e.a. 2020, par. 5.2.3

49. art. 2 sub a en 3 sub a Wet Bibob.

50. art. 8 lid 1 sub a Besluit prudentiële regels Wft; art. 15 lid 1 sub a Besluit Gedragstoezicht financiële ondernemingen Wft.

51. art. 8 lid 2 Besluit prudentiële regels Wft; art. 15 lid 2 Besluit Gedragstoezicht financiële ondernemingen $\mathrm{Wft}$. beschouwd. ${ }^{52} \mathrm{Bij}$ toezicht-, fiscale, of bestuursrechtelijke antecedenten ligt dat anders. Wat volgens onze respondenten vooral als maatschappelijk risico wordt gezien zijn (materiële) normovertredingen van financiële professionals en ondernemingen die het klantbelang ernstig schaden. Formele overtredingen kunnen daarentegen niet zonder meer als integriteitsprobleem worden beschouwd. Respondenten van toezichthouders wijzen onder andere op overtredingen in de informatie- of gegevenssfeer of betreffende de procesorde, zoals kantoorprocedures (BFT), rapportageverplichtingen (AFM en DNB), transparantie- en garantievereisten (ACM) en verzuimen (Belastingdienst). Het is de vraag of bij dergelijk gedrag sprake is van een structureel ernstige tekortkoming die de integriteit van de betrokkene op het spel zet. Dit kan immers ook voortkomen uit onwetendheid, onzorgvuldigheid of onmacht, in plaats van opzettelijk wangedrag. Sanctionering hiervan heeft in sommige gevallen meer het karakter van een spreekwoordelijke tik op de vingers. In geval niet direct schade voor de klant of samenleving uit de overtreding voortvloeit, is het volgens de respondenten van toezichthouders van belang goed te kijken naar de achterliggende oorzaken van het gedrag.

Om een inschatting van de ernst van de overtreding te maken kan vaak niet simpelweg naar de hoogte van een opgelegde sanctie worden gekeken. Zo is een bestuurlijke boete vaak afhankelijk van de omzet van een onderneming en kan het draagkrachtbeginsel ertoe leiden dat deze wordt gematigd. ${ }^{53}$ Mededingingsboetes, waarbij de hoogte tien procent van de omzet van de onderneming wereldwijd kan bedragen, kunnen in de tientallen miljoenen lopen, terwijl omzetgerelateerde boetes bij overtreding van consumentenwetgeving door kleine ondernemingen, zoals webwinkels, heel anders kunnen uitpakken. Ook bij fiscale boetes of bestuurlijke boetes van de AFM en het BFT is de hoogte geen goede graadmeter. Want indien er sprake is van een faillissement en een hoge belastingschuld, dan kan het daarbovenop opleggen van een hoge boete doorgaans weinig opportuun worden geacht. Ten slotte dient altijd rekening te worden gehouden met de draagkracht van de individuele persoon, waardoor een boete lager kan uitvallen dan enkel op grond van de verwijtbaarheid aangewezen zou zijn geweest. Volgens de respondenten van de toezichthouders zou om de ernst van de gedraging te achterhalen dus niet zozeer naar de hoogte van de boete, maar naar de onderliggende feiten en gedragingen moeten worden gekeken.

Het hierboven besproken onderscheid tussen bestuursrechtelijke en strafrechtelijke antecedenten is overigens minder sterk te maken bij overtredingen waarvoor de wet de mogelijkheid tot duale handhaving biedt. In dat geval kan zowel de toezichthouder handhaven als het $\mathrm{OM}$ tot strafrechtelijke vervolging overgaan. Bij deze keuze vormt de zwaarte of ernst van de overtreding in

52. Van 't Zand e.a. 2020, par. 5.2.2

53. Van 't Zand e.a. 2020, par. 5.2.4 
de praktijk niet altijd het doorslaggevende criterium. ${ }^{54}$ Meer pragmatische overwegingen, zoals omtrent de expertise, prioritering, capaciteit, efficiëntie en doorlooptijden, geven soms de doorslag. Ingeval een toezichthouder reeds een grootschalig vooronderzoek heeft verricht, over de benodigde expertise en capaciteit beschikt en het afdoeningstraject (mede daardoor) sneller tot een einde kan worden gebracht, kunnen dit bijvoorbeeld redenen vormen voor bestuursrechtelijk handhaven. Redenen voor strafrechtelijke afdoening houden verband met de (bijzondere) opsporingsbevoegdheden, zoals het kunnen tappen van gegevens, en het ruimere sanctiearsenaal, wat meer soelaas kan bieden dan het opleggen van enkel een bestuurlijke boete. Zodoende kan niet op voorhand worden gezegd dat de zaken waarin strafrechtelijke vervolging plaatsvindt per definitie ernstiger zijn dan die waarbij het bestuursorgaan handhaaft. En hoewel de onderliggende gedraging feitelijk niet anders is, lijken er bij bestuursrechtelijke handhaving vervolgens wel minder (harde) consequenties aan te kleven.

\subsection{Onderliggende feiten en omstandigheden}

Door de respondenten van de toezichthouders wordt voorts benadrukt dat het met het oog op een zorgvuldige afweging belangrijk is de specifieke aanleiding van een toezichtantecedent in ogenschouw te nemen. ${ }^{55}$ Het uitwisselen van 'kale' informatie over opgelegde sancties geeft niet het 'verhaal achter het antecedent' weer. Toezichthouders moeten er bijgevolg op vertrouwen dat een andere instantie discretie aan de dag legt in het betrekken van dit achterliggende verhaal Achter het antecedent gaat immers een (langdurig) toezicht- en handhavingstraject schuil. Zodoende kan de betrokkene nog steeds goed in gesprek zijn met de toezichthouder en naderhand herstel- en beheersmaatregelen hebben getroffen om herhaling te voorkomen. Tevens kan het heel formalistisch gezien zo zijn dat een professional een overtreding heeft begaan, terwijl er allerlei omstandigheden speelden die weliswaar niet oplegging van een maatregel konden voorkomen, maar die wel maken dat deze als minder zwaar wordt beschouwd.

Organisaties die een VOG verplicht stellen, zoals de NBA en DSI, besteden in feite het wegen van justitiële antecedenten uit aan het COVOG. Er wordt gevaren op diens oordeel om wel of geen VOG te verlenen. $\mathrm{Al}$ is voor inschrijving in het accountantsregister de VOG een strikte voorwaarde; bij het screeningsrapport van DSI kan de betrokkene in beginsel ook de afwijzende beschikking van de VOG laten opnemen, omdat het uiteindelijk de werkgever is die het eindoordeel velt en niet de screenende instantie. Juist bij de VOG-beoordeling vindt de minst extensieve toetsing plaats, aangezien alleen justitiële antecedenten tot een afwijzing kunnen leiden en er in principe geen achterliggende feiten en omstandigheden bij de beoordeling worden betrokken. ${ }^{56}$
Er wordt door het COVOG vooral gevaren op de registratie in de justitiële documentatie en op wat de rechter in de strafoplegging tot uitdrukking heeft willen brengen over de ernst van het delict. Er wordt voor gewaakt op de stoel van de rechter te gaan zitten door een eigen inschatting van de ernst van het feit te maken. ${ }^{57}$

Bij TRACK en het LBB vindt naast raadpleging van diverse bronnen ook een meer eigenstandige beoordeling plaats. Deze twee zaken hangen met elkaar samen. Immers kan, zoals gezegd, het type overtredingen waarvoor bestuurlijke maatregelen of sancties kunnen worden opgelegd, zeer uiteenlopend van aard zijn. Derhalve zijn niet alle feiten waarvoor een sanctie is opgelegd even relevant en wordt de achterliggende rapportage opgevraagd om te kijken wat er precies heeft plaatsgevonden en wat de onderliggende omstandigheden en redenen waren die hebben geleid tot handhaving. Door het LBB moet op basis van feiten en omstandigheden die aangeleverd worden vanuit bijvoorbeeld de politie of de Belastingdienst een beoordeling worden gemaakt van het vermoeden dat iemand in relatie staat tot strafbare feiten en hoe ernstig dit vermoeden is. Er vindt een zelfstandige afweging plaats over of de feiten en omstandigheden zwaarwegend genoeg zijn om een vermoeden op te baseren. Hiervoor vaart de beoordelaar niet sterk op het oordeel van het OM of het bestuursorgaan.

Bij de beleidsbepalerstoetsing door de AFM en DNB gaat men duidelijk nog een stap verder, omdat hier ook de houding van de betrokkene ten tijde van de toetsing een belangrijke beoordelingsfactor vormt. Het zogeheten toetsingsgesprek neemt dan ook een belangrijke plaats in het besluitvormingsproces in, waarbij ook een psycholoog of gedragsdeskundige aanwezig is. Er wordt goed gekeken naar hoe de betrokkene staat tegenover wat er eerder is gebeurd, of en hoe hij ervan heeft geleerd, of zijn gedrag is veranderd en wat de instelling zelf ermee heeft gedaan. Dit gesprek vormt zodoende een belangrijke graadmeter voor het betrouwbaarheidsoordeel.

Kortom, om, naast de ernst van de overtreding, de mate van verwijtbaarheid van de overtreder te beoordelen moet er - zo blijkt uit ons empirisch onderzoek volgens zowel de opleggers van de sancties of maatregelen als de beoordelaars ervan, altijd goed gekeken worden naar wat er zich precies heeft afgespeeld. ${ }^{58}$ Op dit vlak lopen de verschillende toetsingen en screening in zekere zin uiteen. Waar op louter justitiële antecedenten wordt gescreend, lijkt in de beoordeling minder ruimte te bestaan dan wel te worden benut voor het betrekken van het achterliggende verhaal. 


\subsection{Praktische obstakels bij gegevensdeling}

Op grond van het voorgaande is duidelijk geworden dat de instanties die een oordeel moeten vormen over de integriteit van professionals of ondernemingen bij voorkeur over zoveel mogelijk en zo gedetailleerd mogelijke informatie dienen te beschikken. Hoe meer onderliggende feiten, omstandigheden en gedragingen zij kunnen meewegen, hoe beter onderbouwd zij tot hun oordeel kunnen komen. Daarvoor is een soepele uitwisseling van gegevens noodzakelijk. De praktijk blijkt echter weerbarstig. ${ }^{59}$ Een eerste praktisch obstakel daarbij is dat alleen voor strafrechtelijke antecedenten een centraal beheerd en voor bevoegden direct raadpleegbaar register bestaat: het Justitieel Documentatiesysteem. Bestuursrechtelijke antecedenten zijn daarentegen sterk versnipperd, zodat een soortgelijk centraal verzamelpunt nog niet beschikbaar en ook niet eenvoudig denkbaar is. Er bestaan immers alleen al ruim 150 verschillende bevoegdheden tot het opleggen van een bestuurlijke boete, die ook nog eens door tal van bestuursorganen kunnen worden uitgeoefend. ${ }^{60}$

Alle in ons onderzoek betrokken toezichthouders kennen voor bepaalde antecedenten een wettelijke publicatieplicht, zoals voor sommige opgelegde bestuurlijke boetes, dwangsommen en ingetrokken vergunningen. Toch vormen deze openbare bronnen geen waterdicht systeem. De praktijk met betrekking tot openbaarmaking laat namelijk aanzienlijke verschillen zien. Zo wordt niet in alle gevallen met naam en toenaam gepubliceerd. De ACM publiceert alleen bedrijfsnamen en publiceert over natuurlijke personen uitsluitend geanonimiseerd. Om met zekerheid te kunnen vaststellen om welke persoon het gaat, zouden in ieder geval voornaam, achternaam en geboortedatum bekend moeten zijn. Screeningsinstanties kunnen derhalve nooit blindvaren op gepubliceerde besluiten. Daarnaast gelden er wettelijke uitzonderingen op de publicatieplicht. Bij wijze van hardheidsclausule kan een uitzondering op openbaarmaking worden gemaakt indien dit onevenredig bezwarend voor de betrokken zou zijn. Door enkel af te gaan op openbare informatie van de website van toezichthouders, kunnen andere instanties dus nooit gegarandeerd over alle bestuursrechtelijke antecedenten beschikken.

Voorts kan informatie op basis van samenwerkingsprotocollen of -convenanten, zowel incidenteel als periodiek, ${ }^{61}$ worden gedeeld. Dit vindt primair plaats op incidentele basis, middels een informatieverzoek in een

59. Van 't Zand e.a. 2020, par. 5.2.5

60. Voor ons onderzoek hebben wij een overzicht samengesteld van alle wettelijke bepalingen waarin een afzonderlijke boetebevoegdheid is opgenomen, zie Van 't Zand e.a. 2020 (te raadplegen via https:// repository.wodc.nl/bitstream/handle/ 20.500.12832/2454/3013_Overzicht_bestuurlijke_boetes_in_NL_weten_regelgeving_tcm28-459640.pdf? sequence=3\&isAllowed=y).

61. Een voorbeeld van periodieke uitwisseling betreft die tussen de ACM en de afdeling COVOG, die ten behoeve van de gedragsverklaring aanbesteden op regelmatige basis (ieder kwartaal) een overzichtslijst ontvangt van beschikkingen opgelegd wegens bepaalde overtredingen van de Mededingingswet. Zie art. 4.7 Aanbestedingswet 2012. individuele zaak. Deze werkwijze levert in de praktijk soms erg lange wachttijden op, terwijl in het bestuursrecht beoordelingstermijnen van tweemaal zes weken gelden. Het kan dan voorkomen dat informatie niet tijdig wordt aangeleverd, zodat een advies uitgebracht moet worden of een beslissing genomen moet worden zonder alle informatie beschikbaar te hebben. Hieraan is een gebrek aan gecentraliseerde systemen in combinatie met verouderde techniek soms mede debet. Bovendien kan ook informatie van buitenlandse toezichthouders van belang zijn, vanwege het grensoverschrijdende karakter van ondernemingen in de financiële sector. Het uitvragen van de juiste bronnen bij buitenlandse toezichthouders is een nog precairder proces, waarin weinig zekerheid bestaat over of alle relevante informatie, tijdig, wordt aangeleverd. Praktisch gezien spelen hier dus behoorlijk wat onzekerheden. Tot slot konden de respondenten in ons onderzoek weinig duidelijkheid bieden over de bewaartermijnen die gelden voor de antecedenten die zijzelf registeren. ${ }^{62}$ In sommige gevallen lopen deze bewaartermijnen ook niet parallel tussen de organisaties die onderling gegevens delen.

\section{Conclusie}

In het voorgaande is het uitgebreide stelsel van wet- en regelgeving, toezicht en screening, samenwerkingsverbanden en informatiedeling gericht op het waarborgen van de integriteit van de financiële sector, in kaart gebracht. Duidelijk is dat er een waaier aan integriteitsinstrumenten voorhanden is, waarbij de diverse typen toetsingen en screenings onderling sterke verschillen vertonen voor wat betreft de doelgroepen, de frequentie, het bereik en de omvang ervan. Ook de specifieke integriteitseisen die aan professionals en ondernemingen worden gesteld en de soorten bronnen die in het integriteitsoordeel worden betrokken, verschillen aanmerkelijk. Tussen de instanties die zich van dit integriteitsinstrumentarium bedienen, bestaan bovendien veel onderlinge dwarsverbanden, langs welke wegen structureel dan wel incidenteel de nodige gegevens worden uitgewisseld. De financiële sector kenmerkt zich aldus door een grote hoeveelheid instanties die integriteitseisen stellen, het gedrag van professionals en ondernemingen toetsen en daarvoor onderling informatie over antecedenten delen.

Dit beeld laat zien dat het waarborgen van integriteit binnen de financiële sector hoog op de agenda staat. Daarmee is echter niet gezegd dat ook sprake is van een goed doordacht, consistent en systematisch opgebouwd stelsel van integriteitstoetsing. Veeleer lijkt sprake te zijn van een bont geschakeerd palet aan toetsingsmechanismen dat in de loop der jaren min of meer organisch is uitgegroeid tot het stelsel zoals we dat thans kennen. Zolang dit stelsel naar behoren functioneert, hoeft dit op zichzelf niet erg te zijn. Toch lijkt het aanbrengen van

62. Van 't Zand e.a. 2020, par. 5.2.5 
een zekere mate van consistentie en systematiek wel aangewezen te zijn, aangezien de doelen en doelgroepen van de diverse screenings voor een belangrijk deel overlappen. Daarbij komt dat iedere instantie over andere bronnen en type antecedenten kan beschikken om het integriteitsoordeel op te baseren. Een overzicht van welke antecedenten, voor welke doelen voor hoe lang relevant zijn, ontbreekt evenwel. Ook de termijnen waarover antecedenten kunnen worden uitgevraagd om deze vervolgens te betrekken in de screening of toetsing, verschillen anzienlijk. Dit komt de voorzienbaarheid niet ten goede. Vanuit het perspectief van individuele rechtsbescherming kunnen de nodige kritische vragen bij dit alles worden gesteld, omdat het daarmee voor natuurlijke personen en rechtspersonen onduidelijk is hoe lang, op welke wijze en in welke contexten bepaalde antecedenten kunnen doorwerken.

Het is goed om daarvoor aandacht te hebben, zeker met het oog op de verwachting dat de komende jaren - in het licht van de politieke en maatschappelijke wens ondermijnende criminaliteit maximaal tegen te gaan eerder een uitbreiding dan een beperking van het integriteitsinstrumentarium en het uitwisselen van antecedenten in het verschiet ligt. Voorts komen daarbij de almaar toenemende mogelijkheden data digitaal te verwerken, te delen en te analyseren. $\mathrm{Nu}$ het totale screeningsstelsel binnen de financiële sector reeds bovengenoemde onzekerheden en onduidelijkheden met zich brengt, is het des te belangrijker voldoende oog te houden voor de gevolgen voor de rechtspositie van de betrokkenen. Hierbij komt onder meer betekenis toe aan de vraag of en in hoeverre enkel onherroepelijk geworden antecedenten in de analyse kunnen worden betrokken. Daarnaast dient de vraag te worden beantwoord of en in hoeverre antecedentenscreening al dan niet dient in te houden dat aandacht wordt besteed aan het verhaal achter het betreffende antecedent. Hoewel integriteitstoetsing aan de hand van antecedenten noodzakelijkerwijze een zekere simplificatie met zich brengt in de zin dat eerdere discussies niet integraal kunnen worden overgedaan, moet - zeker naarmate de mogelijke gevolgen van antecedenten toenemen - ervoor worden gewaakt dat al te zeer met de botte bijl wordt gehakt. 